\title{
Understanding and Analysing the Coordinates of Diversity of Wetland Birds of Asan Barrage near Paonta Sahib, Northern India
}

\author{
Tirshem Kumar Kaushik ${ }^{1}$ and Rohtash Chand Gupta ${ }^{2}$ \\ ${ }^{1}$ Salim Ali Centre for Ornithology and Natural History, Coimbatore, India \\ ${ }^{2}$ Zoology Department, Kurukshetra University, Kurukshetra, Haryana, India \\ E-mail:tarshemkaushik@rediffmail.com/rohtashchandgupta@rediffmail.com
}

Received: 08.11.2013; Accepted: 19.12.2013

\begin{abstract}
The winter migratory wetland bird's diversity of Asan barrage, Uttarakhand, India has been studied during 2005-2012. A total 60 species of wetland birds belonging to 6 orders and 13 families were observed. The findings also hints that Rudy Shelduck Tadorna ferruginea is the most dominant bird followed by Common Coot Fulica atra, Red-crested Pochard Rhodonessa rufina, Common Pochard Aythya ferina and Mallard Anas platyrhynchos. It was observed that Rudy Shelduck preferred Yamuna River waters rather than the traditional still pools, ponds, reservoirs etc. The same trend was displayed by Red-crested Pochard and Great-crested Grebe. On the contrary, winter migratory birds like Northern Shoveller Anas clypeata, Northern Pintail Anas acuta, Common Teal Anas crecca etc were found least in number at Asan Barrage but found in impressive numbers in Haryana traditional pools, ponds.
\end{abstract}

Key words: Tadorna ferruginea, winter migratory birds, Uttrakhand state, India

\section{Introduction}

Long distance migratory birds like Arctic Tern Sterna paradisaea Pontoppidan, White European Storks Ciconia ciconia ciconia L. and Siberian Cranes Grus leucogeranus Pallas, Eastern Curlews Numenius madagascariensis L., Eurasian Crane Grus grus L., Demoiselle Crane Anthropoides virgo L., Ferruginous Pochard Aythya nyroca Guldenstadt, Black-headed Gull Larus ridibundus L., and Greater Scaup Aythya marila L. are globally appreciated for undertaking rarest of the longest journeys from one corner of the world to the opposite side of the earth. So much so, that today, we know about the truthful existence of "International Flyways" adopted by variety of migratory birds across the continents of the earth. In India internationally recognized wetland migratory birds mostly fly over the EurasiaSouth Asia-flyway. Commonly, these wetland migratory birds can be often seen in larger numbers and in rich diversity in Rivers, Lake, Ponds, Reservoirs, confluence of Rivers, Chhapars of all hues in India and Asan Barrage is no exception.

Asan Barrage Wetland attracts copious number of winter migratory birds. The migratory birds of this area have been studied from time to time by considerable number of field ornithologists (Narang, 1990; Gandhi and Singh, 1995; Lopez and Mundker, 1997; Tak et al., 1998; Tak and Sati, 2003). On the other hand, winter 
migratory birds' diversity in traditional ponds in Haryana state, India have also been studied (Gupta et al., 2009; 2010 a-b; Gupta and Kaushik, 2010a-e). Here an attempt has been made to compare the present findings with the previous (Gupta et al., 2009; 2010a- b; Gupta and Kaushik, 2010b,d-e).

The present studies are based on approximately 21 visits made to Asan Barrage during 2005-2012 as per convenience.

\section{Materials and methods \\ Study area}

Asan Barrage wetland (Lat $30^{\circ} 24^{\prime}-30^{\circ} 28^{\prime} \mathrm{N}$ and Long $77^{\circ} 40^{\prime}-77^{\circ} 44^{\prime} \mathrm{E}$ ) is a man made expansive pool of river waters at the confluence of Asan River and Eastern Yamuna Canal at Dhalipur village, $38 \mathrm{~km}$ from Dehradun in Uttrakhand province, India. It is near to Paonta Sahib in Himachal Pradesh and pass by National Highway No. 72 between Saharanpur-Herbetpur. This wetland, also known as Dhalipur wetland, is approximately 450 hect in area and about $287.5 \mathrm{~m}$ long and $389.4 \mathrm{msl}$ elevation (Fig. 1). It has been declared as Asan Conservation Reserve by Govt. of Uttaranchal vide

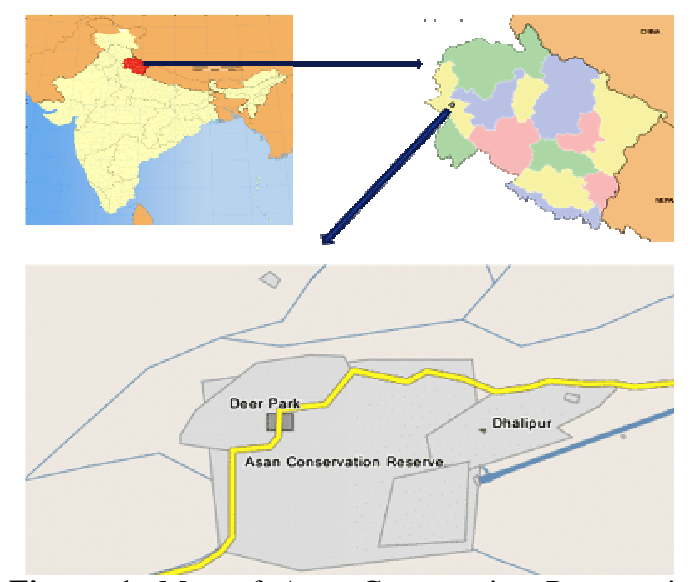

Figure 1. Map of Asan Conservation Reserve in Uttrakhand state in India. notification No. 2414(1) X-2-2005-19(1) 2004 dated 05.08.2005 under section 36A of the Wildlife (Protection) ACT, 1972. It has qualified for attaining the designation, namely, A4i - criteria of wetlands International 2002; Site having $\geq 1 \%$ biogeographic population for being an Important Bird Area (IBA).

\section{Data collection}

The present work was carried out from 2005 to 2012 for the observation of avian diversity of Asan Barrage near Paonta Sahib in Uttrakhand state, northern India. A total of 21 visits were made throughout the study period and visits were made from October to March every year. Average 5-6 hours were spent on observation per visit. Photography was done with camera Zenith attached with 200M tele-lens and Nikon Coolpix P500. So far residential status of wetland birds is concerned, technique developed by Kumar et al. (2003) and Kumar et al. (2005) were adopted. The various categories are Winter Migratory (Birds observed in the winter season only), Resident (Birds observed during all the months of the year) and Local Migratory (Bird species which move within the country and does not come from across the Himalaya). The identification of birds was made following Ali and Ripley (1987), Ali (1996), Grimmet et al. (1998) and Kumar et al. (2005). The nomenclature of birds as given by Manakadan and Pittie (2001) was followed.

\section{Results and discussion}

The present study revealed that a total 60 species of wetland birds belonging to 6 orders and 13 families were observed during the winter seasons of 2005 to 2012 from Asan barrage in Uttrakhand state, Northern 
India (Tab. 1, Pls. 1-2). Order Charadriiformes $(21 \mathrm{sp})$ is the most dominant order followed by Ciconiiformes (16 sp) and Anseriformes (14 sp) (Fig. 2). Anatidae family is the largest one (14 sp) followed by Ardeidae (9 $\mathrm{sp})$ and Scolopacidae (6 sp) (Fig. 3). It is evident from figure 4 that out of 60 species of wetland birds observed from Asan Barrage, 31 species of wetland birds were winter migratory and 9 species of birds were Local Migratory. It is crucial to mention that Gupta and Kaushik (2011) reported 47 species of wetland birds from Hathinikund Barrage in Yamunanagar district in Haryana. Also, Tak et al. (2010) observed 31 species of wetland birds from the Hathinikund Barrage in Yamunanagar district in Haryana.

In the present studies, most dominant winter migratory birds that dotted the water sheet of Asan Barrage include Rudy Shelduck Tadorna ferruginea Pallas followed by Common Coot Fulica atra L., Red-crested Pochards Rhodonessa rufina Pallas, Common Pochards Aythya ferina L., Mallard Anas platyrhynchos L., and Tufted Pochards Aythya fuligula L.. It is worth mentioning that Yamuna Basin in its track through Haryana at points Hathini Kund Barrage, Garhpur Tapu, Kunjpura, Panipat Yamuna Basin, Rudy Shelduck was the most dominant winter migratory birds (Gupta et al., 2012). It is interesting to note that in traditional wetlands in rural area, Rudy Shelduck was not recorded (Gupta $e t$ al., 2009; 2010 a-b; Gupta and Kaushik, 2010a-e). However, in village, namely, Kunjpura, where a very large pond of deep waters is available at a distance of 4-5 km from Yamuna in Karnal, Rudy Shelduck was seen in impressive manner. As such present study revealed that Rudy Shelduck has a penchant for river water and stays away from traditional rural ponds (Gupta and Kaushik, 2011) and may be tempted, once in while, towards large sized ponds.

The Rudy Shelduck is the most dominant winter visitor of Asan Barrage. Birds like Northern Shoveller Anas clypeata, Northern Pintail Anas acuta, Common Teal Anas crecca, Garganey Anas querquedula, Spot-billed Duck Anas poecilorhyncha Forester, Gadwall Anas strepera L. were seen in small number at Asan barrage wetland during the study period. It was found that birds like Northern Shoveller, Northern Pintail, Common Teal, Garganey, Gadwall, Spot-billed Duck were in small number compared to their large number seen in Haryana rural ponds between 2005-2012 (Gupta et al., 2009; 2010 a-b; Gupta and Kaushik, 2010a-e).

The present studies also indicated that birds like Mallard, Eurasian Wigeon Anas penelope L. and Gadwall were seen in mediocre number in Asan Barrage. Gupta and Kaushik (2010b,d-e) have reported the respectable and impressive presence of these birds in rural ponds in Haryana hinting those birds equal preference for river and pond waters. It is evident from table 1 that resident birds like Little Cormorant Phalacrocorax niger Vieillot, Grey Heron Ardea cinerea, River Lapwing Vanellu duvaucelii Lesson, Median Egret Mesophoyx intermedia were found to be present throughout the year. Black-crowned Night Herons Nycticorax nycticorax was seen only on two occasions towards the evening and morning times. Little Egrets Egretta garzetta was found to have been prodigal abundance in winter season in Asan Barrage.

In conclusion, Rudy Shelduck was in large number during October to February. 
Tirshem Kumar Kaushik and Rohtash Chand Gupta / Our Nature (2013), 11(2): 192-200

Table 1. Checklist of wetland birds of Asan Barrage in Uttrakhand state in northern India.

\begin{tabular}{|c|c|c|c|}
\hline \multicolumn{2}{|c|}{$\overline{\text { S.N. Scientific name }}$} & \multirow{2}{*}{$\begin{array}{l}\text { Common name } \\
\text { pedidae }\end{array}$} & \multirow[t]{2}{*}{ Res. Status } \\
\hline & Order- Podicipediformes & & \\
\hline 1 & Tachybaptaus rufficollis Pallas (1764) & Little Grebe & $\mathrm{R}$ \\
\hline \multirow[t]{2}{*}{2} & Podiceps cristatus Linnaeus (1758 & Great Crested Grebe & WM \\
\hline & Order- Pelecaniformes & crocoracidae & \\
\hline 3 & Phalacrocorax niger Vieillot (1817) & Little Cormorant & $\mathrm{R}$ \\
\hline \multirow[t]{2}{*}{4} & Phalacrocorax carbo Linnaeus (1758) & Great Cormorant & $\mathrm{R}$ \\
\hline & & gidae & \\
\hline \multirow[t]{2}{*}{5} & Anhinga melanogaster Pennant (1769) & Darter & $\mathrm{R}$ \\
\hline & Order- Ciconiiformes & dae & \\
\hline 6 & Egretta garzetta Linnaeus (1766) & Little Egret & $\mathrm{R}$ \\
\hline 7 & Ardea cinerea Linnaeus (1758) & Grey Heron & $\mathrm{R}$ \\
\hline 8 & Ardea purpurea Linnaeus (1766) & Purple Heron & LM \\
\hline 9 & Casmerodius albus Linnaeus (1758) & Large Egret & LM \\
\hline 10 & Mesophoyx intermedia Wagler (1829) & Median Egret & $\mathrm{R}$ \\
\hline 11 & Bubulcus ibis Linnaeus (1758) & Cattle Egret & $\mathrm{R}$ \\
\hline 12 & Ardeola grayii Sykes (1832) & Indian Pond-Heron & $\mathrm{R}$ \\
\hline 13 & Nycticorax nycticorax Linnaeus (1758) & Black-crowned Night Heron & $\mathrm{R}$ \\
\hline \multirow[t]{2}{*}{14} & Ixobrychus cinnamomeus Gmelin (1789) & Cinnamon Bittern & WM \\
\hline & & iidae & \\
\hline 15 & Mycteria leucocephala Pennant (1769) & Painted stork & LM \\
\hline 16 & Ciconia episcopus Boddaert (1783) & White-necked Stork & LM \\
\hline 17 & Anastomus oscitans Boddaert (1783) & Asian Openbill Stork & LM \\
\hline \multirow[t]{2}{*}{18} & Ephippiorhynchus asiaticus Latham (1790) & Black necked Stork & LM \\
\hline & & kiornithidae & \\
\hline 19 & Threskiornis melanocephalus Latham (1790) & Oriental White Ibis & LM \\
\hline 20 & Pseudibis papillosa Temminck (1824) & Black Ibis & $\mathrm{R}$ \\
\hline \multirow[t]{2}{*}{21} & Platalea leucorodia Linnaeus (1758) & Eurasian Spoonbill & LM \\
\hline & Order- Anseriformes & & \\
\hline 22 & Anser anser Linnaeus (1758) & Greylag Goose & WM \\
\hline 23 & Anser indicus Latham (1790) & Bar-headed Goose & WM \\
\hline 24 & Tadorna ferruginea Pallas (1764) & Rudy Shelduck & WM \\
\hline 25 & Anas platyrhynchos Linnaeus (1758) & Mallard & WM \\
\hline 26 & Anas strepera Linnaeus (1758) & Gadwall & WM \\
\hline 27 & Anas penelope Linnaeus (1758) & Eurasian Wigeon & WM \\
\hline 28 & Anas poecilorhyncha J.R. Forester (1781) & Spot-billed Duck & WM \\
\hline 29 & Anas clypeata Linnaeus (1758) & Northern Shoveller & WM \\
\hline 30 & Anas acuta Linnaeus (1758) & Northern Pintail & WM \\
\hline 31 & Anas querquedula Linnaeus (1758) & Garganey & WM \\
\hline 32 & Anas crecca Linnaeus (1758) & Common Teal & WM \\
\hline 33 & Aythya ferina Linnaeus (1758) & Common Pochard & WM \\
\hline 34 & Rhodonessa rufina Pallas (1773) & Red-crested Pochard & WM \\
\hline \multirow[t]{2}{*}{35} & Aythya fuligula Linnaeus (1758) & Tufted Pochard & WM \\
\hline & Order- Gruiformes & & \\
\hline 36 & Amaurornis phoenicurus Pennant (1769) & White-breasted Waterhen & $\mathrm{R}$ \\
\hline 37 & Porphyrio porphyrio Linnaeus (1758) & Purple Moorhen & $\mathrm{R}$ \\
\hline 38 & Gallinula chloropus Linnaeus (1758) & Common Moorhen & WM \\
\hline \multirow[t]{2}{*}{39} & Fulica atra Linnaeus (1758) & Common Coot & WM \\
\hline & Order- Charadriiformes & idae & \\
\hline 40 & Hydrophasianus chirurgus Scopoli (1786) & Pheasant-tailed Jacana & LM \\
\hline & Metopidius indicus Latham (1790) & Bronze-winged Jacana & $\mathrm{R}$ \\
\hline
\end{tabular}


Tirshem Kumar Kaushik and Rohtash Chand Gupta / Our Nature (2013), 11(2): 192-200

\begin{tabular}{|c|c|c|c|}
\hline \multicolumn{4}{|c|}{ Family- Charadriidae } \\
\hline 42 & Charadrius dubius Scopoli (1786) & Little Ringed Plover & WM \\
\hline 43 & Charadrius alexandrinus Linnaeus (1758) & Kentish Plover & WM \\
\hline 44 & Vanellus malabaricus Boddaert (1783) & Yellow-wattled Lapwing & $\mathrm{R}$ \\
\hline 45 & Vanellus indicus Boddaert (1783) & Red-wattled Lapwing & $\mathrm{R}$ \\
\hline 46 & Vanellus leucurus Lichtenstein (1823) & White-tailed Lapwing & WM \\
\hline 47 & Vanellus duvaucelii Lesson (1826) & River Lapwing & $\mathrm{R}$ \\
\hline \multicolumn{4}{|c|}{ Family- Scolopacidae } \\
\hline 48 & Tringa erythropus Pallas (1764) & Spotted Redshank & WM \\
\hline 49 & Tringa totanus Linnaeus (1758) & Common Redshank & WM \\
\hline 50 & Actitis hypoleucos Linnaeus (1758) & Common Sandpiper & WM \\
\hline 51 & Tringa nebularia Gunner (1767) & Common Greenshank & WM \\
\hline 52 & Tringa stagnatilis Bechstein (1803) & Marsh Sandpiper & WM \\
\hline 53 & Tringa glareola Linnaeus (1758) & Wood Sandpiper & WM \\
\hline \multicolumn{4}{|c|}{ Family- Recurvirostridae } \\
\hline 54 & Himantopus himantopus Linnaeus (1758) & Black-winged Stilt & $\mathrm{R}$ \\
\hline 55 & Recurivirostra avosetta Linnaeus (1758) & Pied Avocet & WM \\
\hline \multicolumn{4}{|c|}{ Family- Laridae } \\
\hline 56 & Sterna aurantia J.E.Gray (1831) & River Tern & $\mathrm{R}$ \\
\hline 57 & Larus brunnicephalus Jerdon (1840) & Brown-headed Gull & WM \\
\hline 58 & Larus ridibundus Linnaeus (1766) & Black-headed Gull & WM \\
\hline 59 & Larus ichthyaetus Pallas (1773) & Pallas's Gull & WM \\
\hline 60 & Sterna acuticauda J.E. Gray (1831) & Black-bellied Tern & $\mathrm{R}$ \\
\hline
\end{tabular}

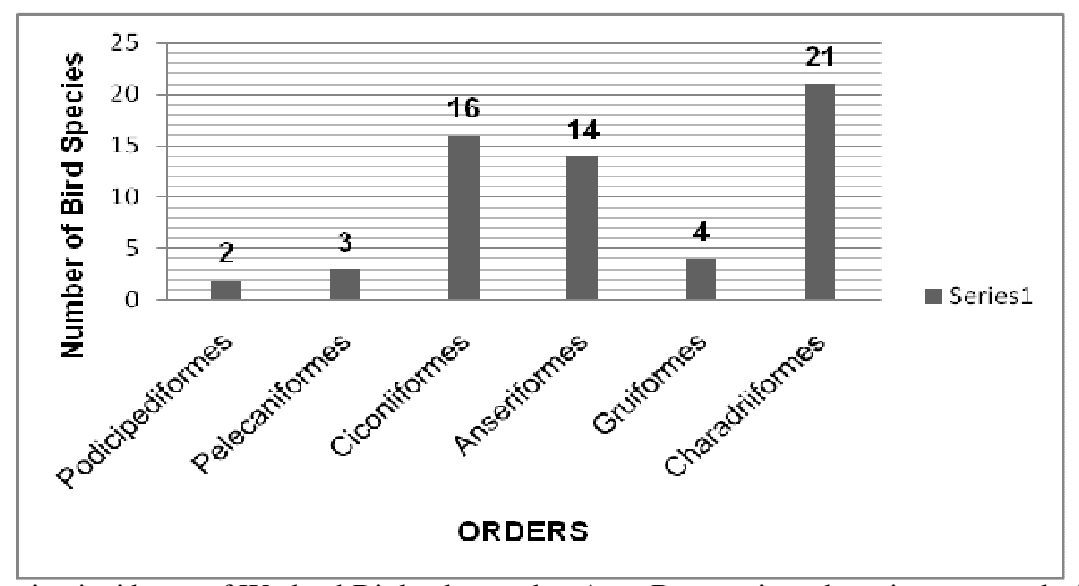

Figure 2. Showing incidence of Wetland Birds observed at Asan Barrage in order-wise manner during 2005-12.

Against the backdrop of studies of Gupta and Kaushik (2010b,d-e) in respect of winter migratory birds in rural ponds in Haryana state, it seems Rudy Shelduck has a strong affinity for River Yamuna waters and always avoids sojourning in rural ponds. However, only such one pond i.e., Kunjpura which is an expansive pond in
Karnal district, nearby $(5 \mathrm{~km})$ Yamuna River, Rudy Shelduck was spotted in sufficient numbers during DecemberJanuary 2008, January 2009, DecemberJanuary 2010 and in the month of February 2012. In view of present studies of birds' diversity at Asan Barrage in Uttrakhand nearby Haryana-Himachal Pradesh Border 
Tirshem Kumar Kaushik and Rohtash Chand Gupta / Our Nature (2013), 11(2): 192-200

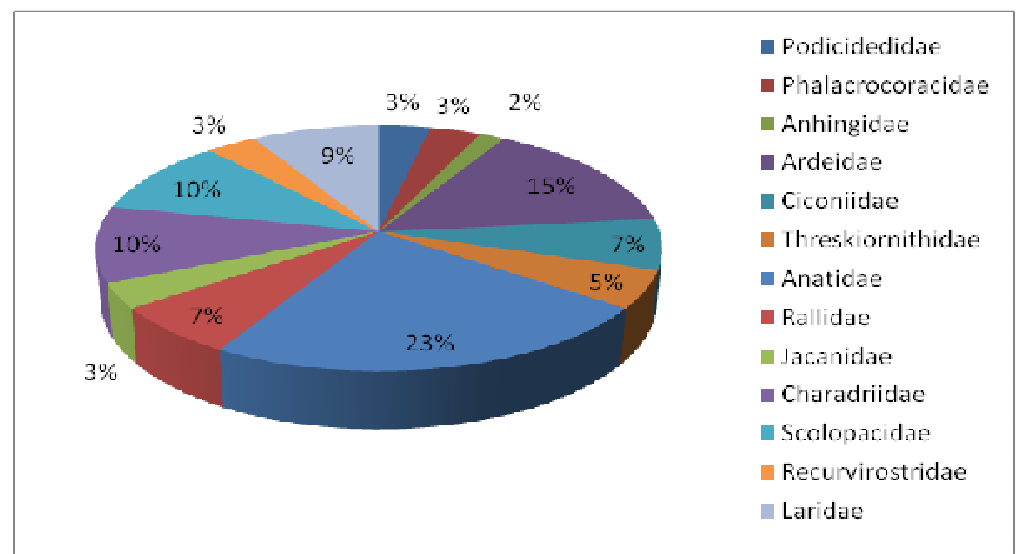

Figure 3. Showing incidence of Wetland Birds observed at Asan Barrage in family-wise manner during 200512.

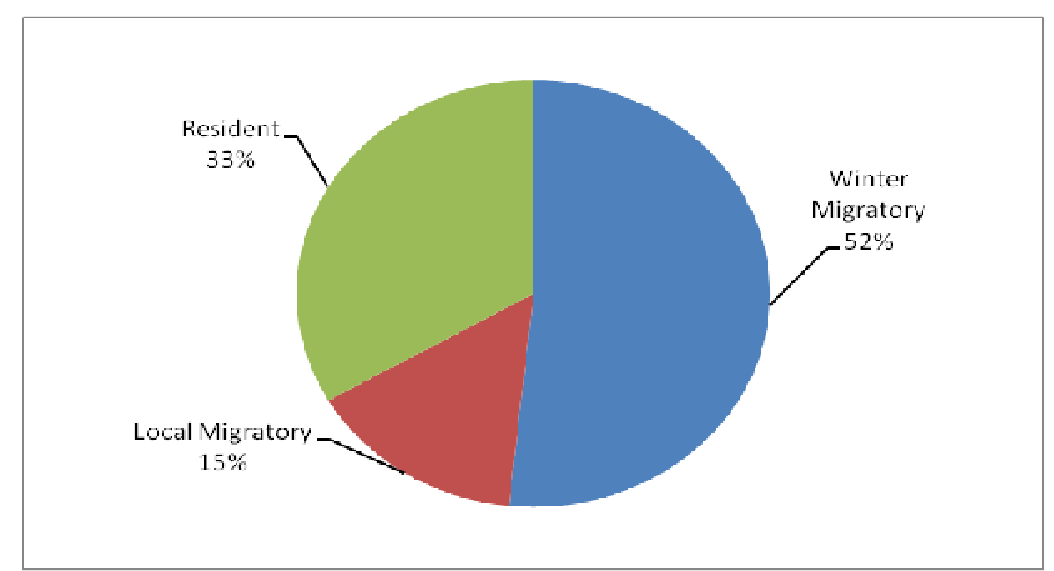

Figure 4. Showing the Residential status of Wetland Birds observed at Asan Barrage during 2005-12.

at the confluence of Asan barrage with Yamuna River, it is recommended that Asan Barrage at Uttrakhand-Himachal-Uttarakhand border in Yamuna River be declared a National Bird Sanctuary with immediate effect. Also, denotified Chilchilla Bird Sanctuary" in Kurukshetra district in Haryana state in India be restored to its original status, its pristine glory rediscovered for the sake of conservation and protection of birds.

\section{Acknowledgements}

The authors feel that "Field Ornithology" is a passion. It must be persuading with a missionary spirit. The authors are thankful to all those ornithologists, who regard field ornithology as their passion and mission leaving no scope for finding excuse for actually going to the field for collection of data. Authors are thankful to authorities of Kurukshetra University including Chairman, Department of Zoology, Kurukshetra University, Kurukshetra.

\section{References}

Ali, S. 1996. The Book of Indian Birds. (Ed. 12, Revised and enlarged) Oxford University Press, Mumbai.

Ali, S. and S.D. Ripley 1987. Handbook of the birds of India and Pakistan together with those of 


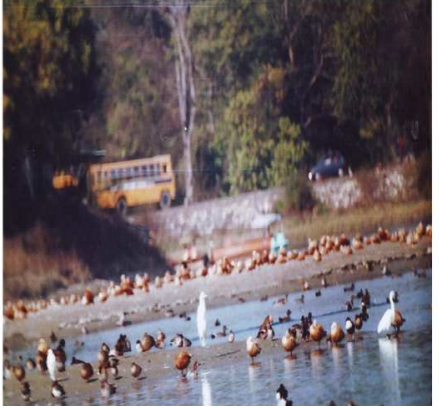

Figure 1. A mixed flock of Ruddy Shelducks, Shovellers and Common Pochards

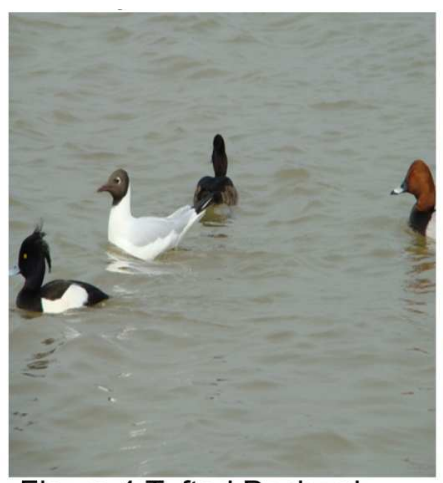

Figure.4.Tufted Pochard and Black-headed Gull

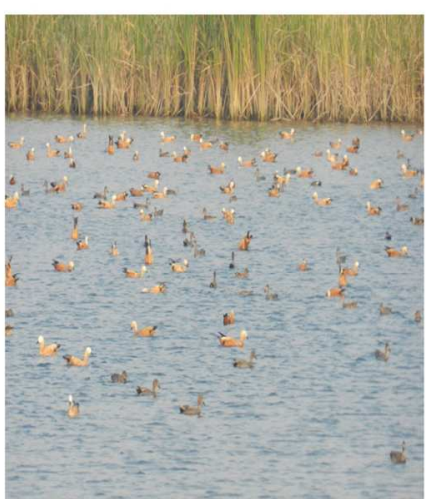

Figure.7. A view of migratory birds at Asan Barrage.

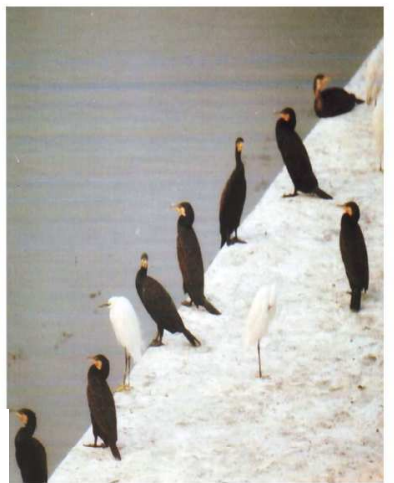

Figure.2 Little Cormorants

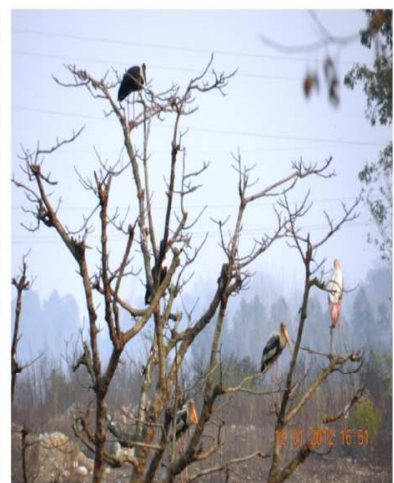

Figure.5. White-necked Storks and Painted Storks.

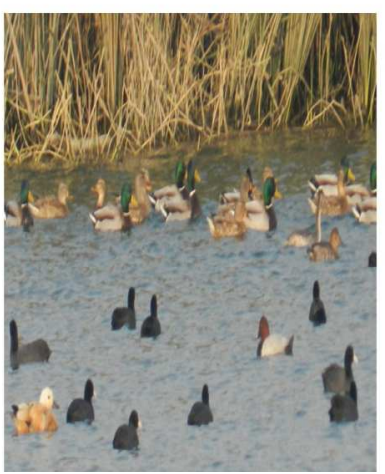

Figure 8. A mixed flock of Mallards, Common Coots, Common Pochards and Ruddy Shelducks

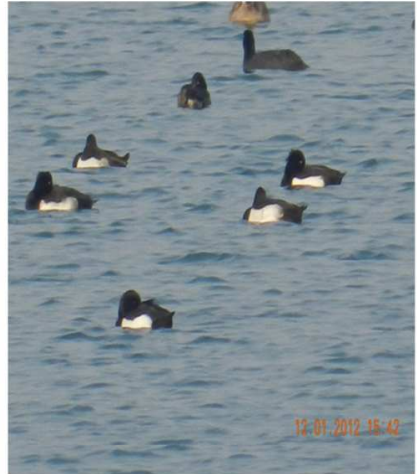

Figure.3 Tufted Pochards

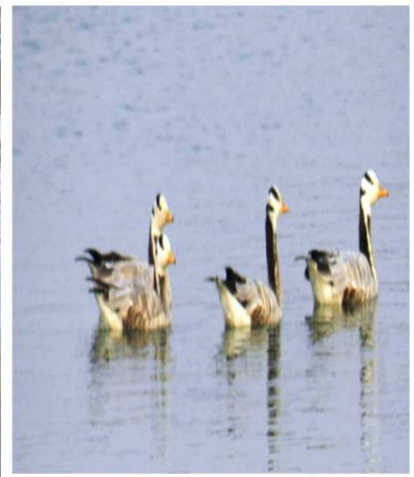

Figure.6. Bar-headed Goose

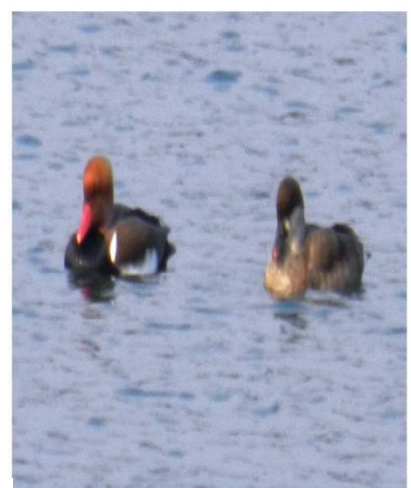

Figure.9. A pair of Redcrested Pochard

Plate-1. Pictorial representations of migratory birds at Asan Barrage in Uttrakhand state in India during 2005-2012. 


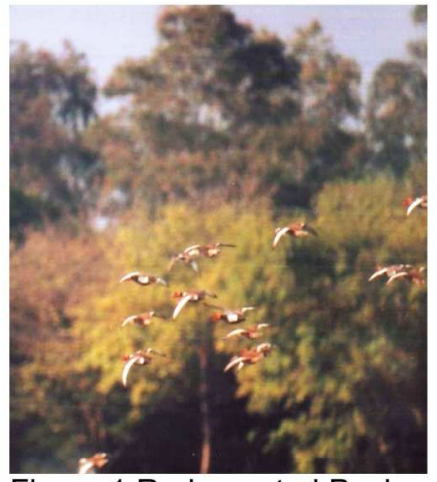

Figure.1.R
(In Flight)

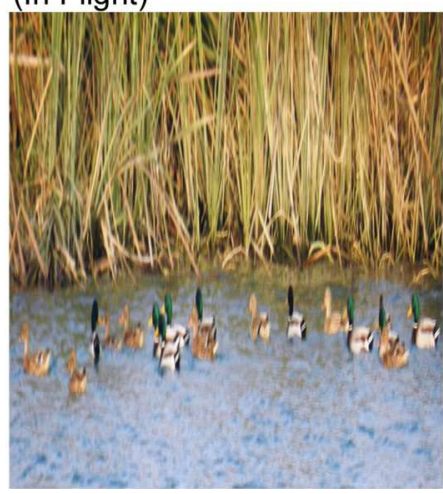

Figure 4. A small flock of Mallards

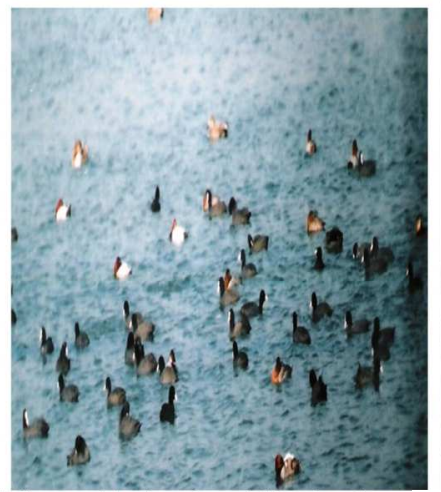

Figure.7. A mixed flock of Common Coots and Redcrested Pochards.

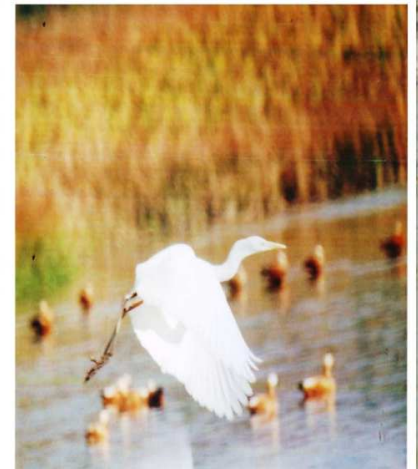

Figure.2.Large Egret (In Flight)

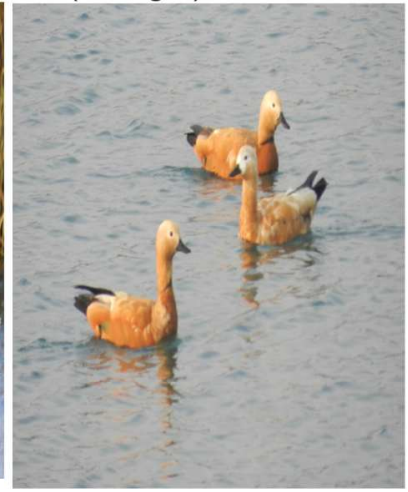

Figure 5. Ruddy Shelducks

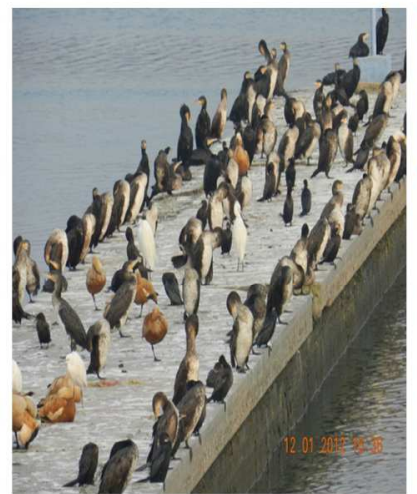

Figure 8. A mixed flock of

Cormorants, Egrets and

Ruddy Shelducks

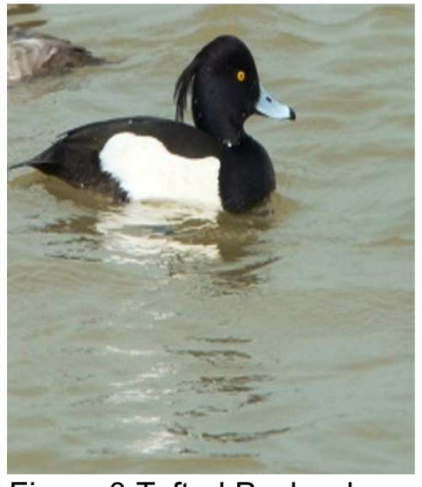

Figure.3 Tufted Pochard

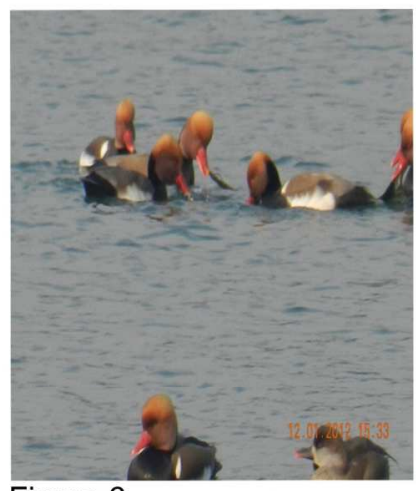

Figure.6.

Red-crested Pochards

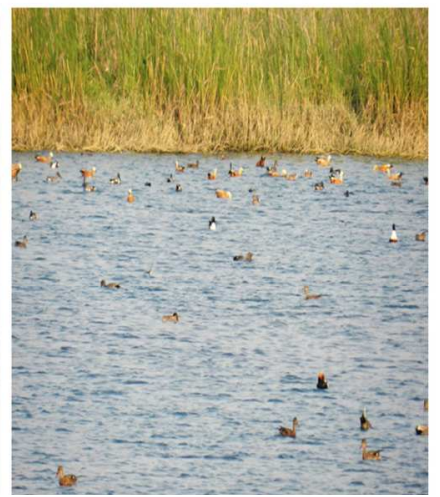

Figure 9. A mixed flock of Northern Shovellers, Gadwalls and Ruddy Shelducks

Plate-2.Photographic representations of Wetland birds at Asan Barrage in Uttrakhand state in India during 2005-12. 
Bangladesh, Nepal, Bhutan and Sri Lanka, Vols. 1-10. Oxford University Press, New Delhi.

Gandhi, S.S. and S.K. Singh 1995. Avifauna of Asan Barrage. Cheetal 34(1): 29.

Grimmet, R., T. Inskipp and C. Inskipp 1998. Birds of the Indian subcontinent. Oxford University Press, Delhi. 888p.

Gupta, R.C. and T.K. Kaushik 2010a. Determination of the domain of spectrum concerning diversity of endangered winter visitor wetland birds in Haryana. Journal of Experimental Zoology 13(2): 349-354.

Gupta, R.C. and T.K. Kaushik 2010b. Computation of wetland birds in rural areas of Kurukshetra, Haryana, India. Journal of Nature Conservation 22(1): 1-11.

Gupta, R.C. and T.K. Kaushik 2010c. On the causative factors responsible for the pathetic plight of Yellow wattled Lapwing in Kurukshetra suburbs. Journal of Nature Conservation 22(2): 181-187.

Gupta, R.C. and T.K. Kaushik 2010d. Determination of spectrum of winter migratory birds in Yamunanagar district in Haryana (India). Environment Conservation Journal 11(3): 37-43.

Gupta, R.C. and T.K. Kaushik 2010e. Understanding Rural Ponds' Migratory Avian Diversity in Panchkula District in Haryana, India. Journal of Advanced Zoology 31(2): 117-123.

Gupta, R.C. and T.K. Kaushik 2011. Insight into wetland winter migratory avian biodiversity in Hathnikund Barrage in Haryana State in India. International Journal of Life Sciences 5(1): 39-43.

Gupta, R.C., P. Chandna and T.K. Kaushik 2012. Analysis of Wetland birds as seen in Yamuna River at Okhla (Delhi), Faridabad and Palwal Districts in Haryana, India. Environment Conservation Journal 13(3): 7-14.
Gupta, R.C., T.K. Kaushik and S. Kumar 2009. Analysis of winter migratory Wetland birds in Karnal district in Haryana. Journal of Advanced Zoology 30(2): 104-117.

Gupta, R.C., T.K. Kaushik and S. Kumar 2010a. Evaluation of the extent of wetland birds in district Kaithal, Haryana, India. Journal of Applied and Natural Science 2(1): 77-84.

Gupta, R.C., T.K. Kaushik and S. Kumar 2010b. An account concerning arrival and departure time of few selected winter migratory birds in Haryana rural ponds. Environment Conservation Journal 11(1-2): $1-9$

Kumar, A., J.P. Sati and P.C. Tak 2003. Checklist of Indian water birds. Buceros 8(1): 1-30.

Kumar, A., J.P. Sati, P.C. Tak and J.R.B. Alfred 2005. Handbook on Indian wetland birds and their conservation. Zool. Surv. India. 468p.

Lopez, A. and T. Mundker 1997. In The Asian Waterfowl Census 1994-96. Wetlands International 1: 118.

Manakadan, R. and A. Pittie 2001. Standardised common and scientific names of the birds of Indian subcontinent. Buceros 6(1): 1-38.

Narang, M.L. 1990. Migratory waterbirds of Dhalipur Lake near Dehradun (U.P.). Indian Journal of Forestry 13(1): 63.

Tak, P.C. and J.P. Sati 2003. AVES. In fauna of Asan wetland, wetland ecosystems series. Zoological Survey of India 5: 31-38.

Tak, P.C., J.P. Sati and A. Kumar 1998. Waterfowl potential of Asan Reservoir (Dehra Dun Valley, India). Zoologie 5(2): 111-132.

Tak, P.C., J.P. Sati and A.N. Rizvi 2010. Status of waterbirds at Hathnikund Barrage wetland, Yamunanagar District, Haryana, India. Journal of Threatened Taxa 2(4): 841-844. 